\title{
Historiadores e musicólogos: vozes dissonantes sobre Villa Lobos no Estado Novo
}

Historians and musicologists: dissonant voices about Villa Lobos during the Vargas era

Los historiadores y musicólogos:voces en Villa Lobos disonantes en Nuevas condiciones

João HenriqueZanelatto*

Carlos dos Passos Paulo Matias ${ }^{*}$

\section{Resumo}

Getúlio Vargas, durante o período que esteve no poder, em especial durante o Estado Novo procurou cooptar muitos intelectuais - pintores, escritores e músicos, a fim de se legitimar no poder. Mas em que medida tais intelectuais aderiram ou não, deram ou não sustentação para o governo Vargas? Essa questão tem provocado muitos debates e análises na academia. O maestro Heitor Villa-Lobos vivenciou o período em que Vargas esteve no poder e trabalhou para seu governo. Assim, este trabalho busca, demonstrar como o maestro Villa foi visto pelos historiadores e como ele foi visto pelos musicólogos durante o Estado Novo. Levanta-se, assim, uma ardente discussão entre musicólogos e historiadores, sobre a postura do maestro, como intelectual e como co- ordenador de um programa de educação musical, durante o Estado Novo.

Palavras-chave: Vozes Dissonantes. Villa Lobos. Estado Novo

\section{Introdução}

A polêmica em torno da originalidade na música popular brasileira, que também afetou a criação musical de Villa-Lobos, se-

* Doutor em História pela Pontifícia Universidade Católica do Rio Grande do Sul. Professor do Curso de História e do Programa de Pós-Graduação em Desenvolvimento Socioeconômico da Universidade do Extremo Sul Catarinense - Unesc.

** Mestre em Educação pela Universidade do Extremo Sul Catarinense. Professor do Curso de História da Universidade do Extremo Sul Catarinense - Unesc.

Recebido em 21/03/2014 - Aprovado em 04/08/2014 http://dx.doi.org/10.5335/hdtv.14n.2.4582 
gundo os implacáveis críticos de sua obra, passou por um processo que, em sua gênese, nada tem de "folclórico" e sofre uma verdadeira operação de autenticação cultural (NAPOLITANO, 2002). Essa busca de identidade da cultura brasileira, o movimento modernista com A Semana de Arte Moderna em 1922, e uma excitante dissonância entre os musicólogos e os historiadores, que até hoje gera ardentes debates, em aspectos no que tange à visão que se vê Heitor Villa-Lobos, levou-nos a fazer esta pesquisa bibliográfica.

A pesquisa buscará, por meio de análises das obras de alguns musicólogos e historiadores, trabalhar como a história, através dos historiadores, e como os musicólogos, e estudantes da música, veem o Maestro Villa-Lobos durante o Estado Novo.

Buscamos nos musicólogos Vasco Mariz (2005), Arnaldo Magalhães de Giacomo (1960), Maria Maia (2000) e outros, um pouco da obra e da vida do maestro Villa-Lobos, que aparece na fala desses entusiasmados estudiosos, como um "gênio" que não deve ser esquecido jamais. Mariz é considerado o maior estudioso da Vida e da Obra do maestro, e descreve Villa-Lobos como um músico erudito do Século XX. Villa um "brasileiro" que conseguiu projeção mundial como um dos "gênios" da música do século passado. Segundo Mariz, um brasileiro que não negou sua origem nem morando fora do país, Villa sempre fez questão de dizer, em todos os lugares por onde passou que era brasileiro, e que muito lutou para que o mundo conhecesse um pouco da música brasileira por meio de suas obras.

Buscamos nos historiadores Marcos Napolitano (2002), Adalberto Paranhos
(1999) e Arnaldo Contier (1998) um pouco da história do músico Heitor Villa-Lobos. Villa, atuando no Estado Novo como coordenador de um megaprojeto musical, segundo o qual todo o Brasil deveria cantar, financiado pelo governo e executado sob a batuta do Maestro.

Contier (1998) traz um detalhado estudo sobre a criação e o desenvolvimento do projeto musical de Villa-Lobos para a educação durante o Estado Novo. Paranhos (1999) faz uma minuciosa análise da construção da ideologia trabalhista no Estado Novo e as ferramentas usadas pelo regime para legitimar esses ideais. Napolitano (2002), aponta para a trajetória da música popular do Ocidente, o folclore, a música e a história do Brasil.

Enfim, procura-se contribuir iniciando com um breve histórico da vida do maestro nos anos 1920 e 1930; uma sintética discussão sobre a música popular, os acontecimentos políticos, o Movimento Tenentista, o fim da Primeira República, o movimento de 30, os aspectos artísticos da época, destacando a Semana de Arte Moderna e a participação de Villa-Lobos no evento. Destacamos ainda a ascensão de Vargas ao poder com o movimento de 30 e uma sintética discussão sobre a formação da música popular brasileira. Em seguida, focaremos Villa-Lobos e seu projeto musical para a educação no Estado Novo, na ótica/representação dos musicólogos e dos historiadores. Intercalando obras de historiadores, musicólogos, críticos de música e estudiosos dos acontecimentos do período histórico, busca-se demonstrar como os historiadores e os musicólogos veem Villa e sua música sob a batuta de Vargas. 
0 Brasil e o músico nas décadas de 1920 e 1930

"Não sou Futurista nem passadista, eu sou eu"

H. Villa-Lobos.

Não vejo nenhuma necessidade de defender tudo o que é feito em nome dos estudos culturais, tal como não preciso defender tudo que é feito em nome do socialismo, feminismo, ou mesmo da democracia. Afinal de contas, slogans são slogans, seu objetivo é arregimentar uma formação. Como as senhas, eles são mais bem encarados como sinal de perguntas comum, não de respostas comuns, o roubo de slogans é um dos instrumentos chave das lutas ideológicas (DENNING, 2005, p. 159).

A citação anterior dá uma ideia do que se pode fazer com um projeto, seja ele cultural ou não. E o que se pode fazer com um bom jogo de palavras ou frases. Usar um slogan como um fim para um suposto "mal", ou um início para um suposto "bem", pode dar resultados esperados, ou não. Buscar uma "brasilidade", ou uma "originalida$\mathrm{de}^{\prime \prime}$, numa perspectiva de uniformidade de "gosto", "tradição" ou aculturação, não deixa muito esclarecido, a contradição: criar ou imitar? A cultura brasileira, durante as décadas de 1920 e 1930, ferveu com esse sentimento de "não definição" do que é e o que não é arte genuinamente brasileira.

Villa-Lobos a essa altura, já tinha percorrido grande parte do território brasileiro, pesquisando seus sons e sua gente: como cantam? Como tocam? Como vivem? Ter clareza do que se pode fazer com um slogan, será de total importância para a reflexão que será feita nesse trabalho, quando buscamos destacar a figura do músico Heitor Villa Lobos - músico popular? Dos anos 1920 até o Estado Novo, Villa na ótica dos historiadores e na ótica dos musicólogos.

A polêmica em torno da originalidade na música popular brasileira, que também afetou a criação musical de Villa-Lobos, segundo os implacáveis críticos de sua obra, passou por um processo que em sua gênese nada tem de "folclórico" e sofre uma verdadeira operação de autenticação cultural (NAPOLITANO, 2002). Criam-se mitos e muitos preconceitos em relação à nossa música. Chega-se ao ponto de haver discussões sobre que é samba. ${ }^{1}$ Debates, esses, que nada contribuem para o enriquecimento da nossa música ou dos nossos músicos. Eles servem muito mais para criar certa distinção de ritmos, utilizados para hierarquizar a música popular brasileira, e não para complementá-la. O maestro Villa-Lobos foi um "problema" para os críticos, pois compôs Óperas, Choros e todos os ritmos "que corriam em suas veias." E a crítica, como se sabe (?), insiste em encontrar um "estilo" (de preferência burguês, pois é o "melhor", o mais "sério") para enquadrar o artista.

"Somente uma aliança entre setores intelectualizados nacionalistas e a "verdadeira" cultura popular musical pode afirmar a "brasilidade" e evitar que ela perca autenticidade e legitimidade" (NAPOLITANO, 2002). Essas bases de pensamento da música popular brasileira ajudaram a constituir a tradição, foram filtros da memória e carregam em si as marcas de uma historicidade peculiar (a reorganização das bases culturais nacional, entre os anos 1920 e 1930, e seu questionamento nacionalista, à esquerda, nos anos 
1950 e 1960) (NAPOLITANO, 2002). Mas, ao longo dessa trajetória, outras historicidades irão intervir no redimensionamento e na revisão dessas bases estético-ideológicas, não só do samba, mas do próprio conceito de música popular brasileira. Isso fica claro, por exemplo, no status que alcançou um piano no Império e na Primeira República (toda família de "bem" que se prezava comprava um piano para a filha aprender), e o status que não tinha um violão (instrumento de vadio, de músico não "erudito").

Mapear e criticar essas bases de pensamentos e intervenção cultural nos ajuda a superar uma visão excessivamente linear da música brasileira, que tende a organizar uma trajetória histórica multifacetada e híbrida em eventos, personagens e gêneros excessivamente delimitados, organizados e analisados na forma de juízos de valores que, apesar de inevitáveis e necessários para a experiência estética da música, podem conter armadilhas para a interpretação histórica (NAPOLITANO, 2002).

Existem muitas obras escritas sobre a vida de Villa-Lobos no Brasil e no mundo, porém há certo consenso entre esses escritores, como o de "que não é uma tarefa fácil, definir o que é e quem foi Villa-Lobos". Escutar a música de Villa-Lobos é a melhor forma de conhecê-lo e dimensionar sua importância para a cultura (formação da alma musical) do Brasil (MAIA, 2000). A vida do maestro é estudada em vários países por onde ele apresentou suas obras e foi regente das orquestras locais. Villa regeu na Europa, Oriente Médio, Ásia, América do Norte e vários países da América Latina. E criou muitas orquestras no Brasil.
Villa-Lobos nasceu no dia 5 de Março de 1887, na rua Ipiranga, em Laranjeiras, naquele tempo um dos bairros mais verdes e floridos da cidade do Rio de Janeiro. Filho de Raul Villa-Lobos (que era músico) e Dona Noêmia Monteiro Villa-Lobos, o pequeno Tuhu - como era chamado o menino - desde cedo teve contato com a música clássica. $\mathrm{O}$ ambiente musical foi de grande importância na formação musical do futuro gênio. A mãe não queria que Tuhu fosse músico, ela sonhara para o filho uma carreira de doutor, de preferência a de médico, mas o menino não era muito chegado aos estudos, o que não quer dizer que o rapaz não fosse curioso. À medida que o tempo ia passando e Heitor ia crescendo, a família (nesse caso a mãe, pois o pai veio a falecer quando Heitor tinha 13 anos de idade) percebia claramente que Villa não seria outra coisa, se não um grande músico (DOMINGO E CÁTIA, 2001).

Com a morte do pai, Villa, já com seu desejo musical aguçado, sabia onde encontrar a verdadeira música brasileira. O rapaz passa a tocar violão, instrumento que não era muito valorizado pela "sociedade" que ouvia a "boa música", com um grupo de chorões. Escondido da mãe ele se juntava a esses músicos de seresta para tocar na noite carioca. O contato com esses músicos da noite, que não tocavam a música que o seu pai tocava, pois o pai tocava música clássica, despertou no rapaz a necessidade de buscar, em algum lugar a verdadeira musica brasileira.

No Brasil, durante a década de 20, enquanto aos poucos chegam às ideias modernas europeias, a organização política e social da Primeira República começa a sofrer os primeiros abalos. A sociedade brasileira viveu 
um período de grande efervescência e profundas transformações. Mergulhado numa crise cujos sintomas se manifestaram nos mais variados planos (econômico, político, cultural e social), o país experimentou uma fase de transição cujas rupturas mais drásticas se concretizariam a partir do movimento de 1930 (MORAIS e CONDE SÁ, 1930).

Os espíritos fin de siècle (final do Século XIX) apagavam-se na Europa, onde havia uma inquietação no meio artístico representada por Cocteau, por Schonberg e outros. Brasileiros que estudavam arte em Paris participavam também desse processo renovador que posteriormente se refletiu no Brasil.

O primeiro "escândalo" deu-se em 1917, em São Paulo, com a exposição da pintora Anita Malfatti, recém-chegada de Munique, merecendo a sua pintura uma descompostura do "acadêmico" Monteiro Lobato. Surgiram outros vanguardistas, como o escultor Vítor Brecheret. Em 1919 Manuel Bandeira publicava o Carnaval e rompia com os parnasianos. Mário de Andrade escrevia a sua Paulicéia Desvairada e Ronald de Carvalho fazia os seus Epigramas. Villa-Lobos, por esse tempo, já tinha um público, já merecera o elogio caloroso de um Rubistein, embora Villa fosse ainda muito combatido.

Assim, já havia um movimento modernista que não nasceu, evidentemente, com a Semana de Arte Moderna, realizada no Teatro Municipal de São Paulo, em fevereiro de 1922. A semana foi apenas a representação oficial desse movimento que, ainda tímido, já existia no eixo cultural Rio - São Paulo. Mário de Andrade, na conferencia que fez no Rio, em 1942, dizia entre outras considerações:
O movimento modernista era nitidamente aristocrático. Pelo seu caráter de jogo arriscado, pelo seu espírito aventureiro ao extremo, pelo seu internacionalismo modernista, pelo seu nacionalismo embrabecido, pela sua gratuidade antipopular, pelo seu dogmatismo prepotente, era uma aristocracia do espírito. Bem natural, pois, que a alta e pequena burguesia o temessem (PELLEGRINI, 1996, p. 87-96).

E foi no meio dessa tremenda assuada, dos maiores insultos, que a Semana de Arte Moderna abriu a segunda fase do movimento modernista, o período realmente destruidor. Porque, na verdade, o período heróico fora esse anterior, iniciado com a exposição de pintura de Anita Malfatti e terminando na festa da Semana de Arte Moderna:

Durante essa meia dúzia de anos fomos realmente puros e livres, desinteressados, vivendo numa união iluminada e sentimental das mais sublimes. Isolados do mundo ambiente, caçoados, evitados, achincalhados, malditos, ninguém não pode imaginar o delírio ingênuo de grandeza e convencimento pessoal com que reagimos. $\mathrm{O}$ estado de exaltação com que vivíamos era incontrolável. $^{2}$

Os modernistas advogavam três princípios fundamentais: o direito permanente à pesquisa estética, a atualização da inteligência artística brasileira, e a estabilização de uma consciência criadora nacional. Pela imprensa, uma facção contrária à Semana assim se manifestou:

[...] representou-se ontem o último ato de bambochata futurista. O senhor Villa-Lobos, pelo seu talento musical, bem merecia não ter se metido com a meia dúzia de cretinos que transformaram o nosso Municipal em dois espetáculos memoráveis pela sandice, numa desoladora grita de feira (PELLEGRINI, 1996, p. 102). 
Villa-Lobos contava como fora a sua participação na Semana. Tinha sido procurado, na sua casa, por Graça Aranha e Ronald de Carvalho, para lhe expor o plano e expor sua adesão. Havia gostado da proposta, pois coincidia com as ideias pelas quais vinha lutando há anos. Mas, para ir a São Paulo havia um empecilho sério: não dispunha de meios suficientes para uma viagem tão dispendiosa, com o seu grupo. Os amigos voltaram depois com Paulo Prado e lhe pediram um programa com o respectivo orçamento. Villa pode então, com carta branca de Paulo Prado, contratar os melhores artistas e seguir para São Paulo.

Sobre o que foi esse acontecimento, Villa escreve ao amigo Iberê Lemos:

Quando chegou a vez da música, as piadas das galerias foram tão interessantes, que quase tive a certeza de a minha obra atingir um ideal, tais foram as vaias que me cobriram de louros. No segundo, a mesma coisa na parte musical, e na parte literária a vaia aumentou. Chegamos ao terceiro concerto, que era em minha homenagem que susto passaram os meus intérpretes, vais ver... Organizei um bom programa, revestidos dos melhores interpretes. Começamos pelo terceiro trio, que, de quando em quando, um espectador musicista assobiava o principal tema, paralelamente com o instrumento que o desenhava. A Lúcilia e a Paulina queriam parar, eu me ria e o Gomes bufava, mas foi até o fim. Nos outros números, novas manifestaç̃es de desagrado, até ao ultimo número, que foi o quarteto simbólico, onde consegui uma execução perfeita, com projeção de luzes e cenários apropriados a fornecerem ambientes estranhos, de bosques místicos, sombras fantásticas, simbolizando a minha obra como imaginei. Na segunda parte desse quarteto, lembraste? O conjunto esclarece um ambiente elevado, cheio de sensações novas. Pois bem, um gaiato qualquer, no mais profundo silencio, canta de galo com muita perícia. Bumba... Pôs abaixo toda comoção que o auditório possuía, provocando hilaridade tal que a polícia (finalmente) interveio prendendo os graçolas e mais duas latas grandes de manteiga cheias de ovos podres e batatas. Esses moços, ao serem interrogados, declararam que aqueles presentes estavam destinados a coroarem os promotores da Semana de Arte Moderna em São Paulo, como se fossem flores e palmas, mas que tal fizeram porque respeitavam os intérpretes que na maioria eram paulistas. Uf!... Chega (MARIZ, 1989, p. 167).

Como vemos, não só os conferencistas e poetas da Semana foram vaiados. A música de Villa-Lobos também recebia as patadas de um conservador, resistente a mudanças. O próprio maestro foi ridicularizado. Os espectadores da torrinha ao vê-lo entrar no palco de casaca e chinelo, pois estava doente de um pé, prorromperam em assobios. Durante um dos concertos escorregou a alça do vestido de Paulina e lá das galerias vinha a reação: "levanta a fitinha, moça". Paulina tremia de medo, e ao deixar a cena caiu numa crise de choro. O barítono Nascimento Filho reagia de outra maneira. Quando cantava as últimas notas de uma canção, alguém, nas galerias, gritou: Ridi Pagliaccio. Nascimento respondeu: "desce pra eu te ensinar como se canta". E fez gestos ao público para brigar na rua. O que aconteceu. No dia seguinte, o jovem cantor aparecia para ensaiar com um olho arroxeado... (MARIZ, 1989).

A Semana de Arte Moderna foi apenas um dos acontecimentos dos novos tempos. Pouco a pouco, a reação contra o marasmo das artes e da literatura ganha espaço e co- 
meça a se consolidar, representada em revistas e manifestos. Além disso, os ecos da Semana chegaram a outras regiões do país, disseminando as ideias modernistas. Descentralizava-se a vida artística, antes restrita ao Rio e a São Paulo. O período imediatamente posterior à Semana, que vai até 1930, é conhecido como a primeira fase modernista, ou "fase heróica". A palavra de ordem é: liberdade. Liberdade era o sentimento que mais existia em Villa-Lobos, pois a essa altura o maestro já tinha percorrido todo o território brasileiro atrás da nossa "verdadeira música", e teria dito: "a música brasileira começa comigo" (MARIZ, 2005).

Embora Carlos Gomes tenha sido o primeiro compositor brasileiro a atingir fama internacional com a ópera O guarani (1870) e, mais do que isso, tenha constituído a ser emulado ou superado pelas gerações subsequentes, Villa-Lobos foi aclamado como o primeiro compositor verdadeiramente brasileiro por ter realizado a mais completa e genuína síntese da "alma brasileira". Em 1923, Villa faz sua primeira viagem à Europa, fixando-se em Paris. Até 1930, o maestro faz algumas viagens a Paris, pois Paris é o centro do mundo cultural. Em 1930, Villa-Lobos volta ao Brasil a convite de D. Olívia Penteado para realizar concertos em S. Paulo. Elabora também um plano de educação musical que é apresentado à Secretaria de Educação de S. Paulo. Com o Movimento de 30, o interventor de S. Paulo João Alberto, convida Villa-Lobos para debater seu plano de ensino (MARIZ, 2005).

\section{0 educador Villa-Lobos e 0 Estado educador}

Getúlio Vargas chega ao poder em 1930 e em 1937, logo após o golpe institui o Estado Novo. Esse se configuraria no período mais autoritário da era Vargas. Constituiu-se, no período, o projeto de ordenamento da sociedade - corporativismo que se apoia inteiramente na imagem de organicidade do corpo. A sacralização do "corpo que trabalha". Os regimes autoritários e totalitários têm forte apego à sacralização do político como instrumento de dominação. O Estado Novo vai criar um novo conceito de trabalho e trabalhador - forjamento do trabalhador despolitizado, disciplinado e produtivo. $\mathrm{O}$ Estado pretendia "educar o trabalhador de modo a arranca-lo da sua condição de classe, diluindo-a no corpo nacional, fazendo dele um trabalhador ordeiro e produtivo" (LENHARO, 1986, p. 38). O discurso do corporativismo, do trabalhismo e de unidade nacional permeou toda a era Vargas, em especial no Estado Novo.

De fato, no discurso mítico do trabalhismo o mito de doação ocupou lugar central. Getúlio Vargas, o líder populista de maior prestígio que o Brasil já conheceu, teve sua trajetória política particularmente associada à "outorga" das leis "protetoras" do trabalho, ponto de honra na imagem popular que dele se projetou. $\mathrm{O}$ mito da doação se propagou com maior intensidade, principalmente a partir do "Estado Novo", e pela sua difusão tentou fazer crer que a legislação social não passaria de uma dádiva caída dos céus getulistas sobre a cabeça dos trabalhadores brasileiros (PARANHOS, 1999, p. 23). 
É nesse cenário, segundo Paranhos, "mitológico," em que dos céus vêm a organização "protetora" do trabalho, graças à incansável doação de seu "chefe" mais "querido" e mais prestigiado que o Brasil já conheceu, nesse cenário ufanista que o maestro Villa-Lobos estará desenvolvendo sua música e idealizando seus projetos para a música brasileira e para a educação musical da nação. Esse era um bom motivo para se apoiar "qualquer projeto cultural" que "unisse" a nação e legitimasse Vargas no poder.

Novamente no Brasil, Villa-Lobos, agora com 43 anos, está em São Paulo [...], apesar da cidade estar com uma atmosfera revolucionária nesta época - 1930. O maestro sente-se feliz em São Paulo, trabalha, rege, vive a arte em toda sua plenitude. É com os estudantes, os jovens, que o Maestro irá organizar sua "exortação Cívica". A estes junta soldados da polícia, estudantes das escolas secundárias, seminaristas, padres e outros. As autoridades se entusiasmam, prestigiam o movimento. $\mathrm{O}$ Interventor João Alberto patrocina-lhe, em seguida, uma viagem ao interior do Estado (GIACOMO, 1960, p. 79-81).

Fica evidenciado na citação o ideal de coesão, civismo no trabalho de Villa-Lobos e a felicidade e entusiasmo presentes nas autoridades do governo. A música contribuiria para romper todas as barreiras sociais e serviria de "elo" entre as classes, pois todos passariam a gostar de música brasileira, independente da classe.

Mas antes de demonstrar o músico Villa-Lobos no Estado Novo de diferentes ângulos, transcrevemos trechos de um artigo publicado na revista Diapason (2006) intitulado "O verdadeiro Tropicalista", do compositor e musicista Gilberto Mendes, para dar mais consistência à discussão aqui proposta.

Existe, curiosamente, uma questão Villa-Lobos entre nós, músicos brasileiros. Apesar de ele ser uma glória nacional, de seu nome ser conhecido até pela grande massa, que não freqüenta concertos, e de um portentoso shopping center de São Paulo ter o seu nome, sempre houve, por parte de alguns artistas e intelectuais, e ainda há, uma certa rejeição à sua pessoa, à sua música (MENDES, 2006, p. 28).

Mendes, que é musicólogo e compositor, considerado um importante músico brasileiro vivo, aos 84 anos; começa dando um puxão de orelha na sua classe, ${ }^{3}$ já que, sendo essa, por excelência, a classe musical, é quem deveria defender incondicionalmente a memória e a obra de Heitor Villa-Lobos. É forçoso dizer que para o historiador e para a história, o contato com a música de Villa e com o Maestro aparece de formas diferentes. Os leigos no assunto ouvem pela primeira vez o nome Villa-Lobos por meio das aulas de história, o que nos preocupa, pois temos muitos professores de história que não sabem quem foi Villa-Lobos, ou o conhecem muito superficialmente; já os cursos de música no país são escassos, e, nas séries iniciais, os alunos não têm contato com a história da música, o compositor Mendes não tira do artista o brilho de sua obra nem o torna menos importante no cenário musical mundial. Num outro trecho do artigo ele diz:

Não falo daquela histórica aversão que os acadêmicos conservadores sempre têm com relação ao novo, à vanguarda. Villa também provocou essa aversão no início de sua carreira. Basta lembrarmos o crítico Oscar Guanabarino, que tanto o detestava, acu- 
sando-o de desconhecer as regras fundamentais da composição. Estou me referindo a um tipo de prevenção, um preconceito, na verdade, que sentimos muitas vezes com relação à sua figura no cenário geral das artes brasileiras (MENDES, 2006, p. 28).

Na citação anterior, Mendes lembra um crítico de Villa-Lobos, contemporâneo do maestro, e faz uma associação ao conservadorismo "que ainda existe nas academias", e a dificuldade que músicos, críticos e intelectuais, que conheceram a música de Villa nas suas primeiras audições tiveram para aceitar algo inovador. Ele subestima os reacionários e convida-os a deixarem de lado o preconceito e reconhecer o maestro como inovador das artes, entenda-se música-brasileira. Em um último momento ele diz:

Acontece que Villa não é o nacionalista que os partidários de uma música nacionalista conservadora pensam ou desejam que seja. Eles não podem entende-lo de fato porque, em seu total significado, Villa já é um verdadeiro tropicalista, muito antes do tropicalismo. Trata-se de um outro conceito da coisa brasileira (MENDES, 2006, p. 28-29).

Nessa incisiva afirmação, Mendes subestima os partidários de uma música nacionalista, dizendo que Villa já era tudo aquilo que se vai criar de novo! Na Semana de Arte Moderna, Villa já era modernista muito antes; no movimento Tropicalista, Villa já havia pensado e feito música como os tropicalistas. E no Estado Novo, Villa-Lobos é um compositor nacionalista? Ou Villa é um músico idealista? O que Villa-Lobos é, ou o que ele foi talvez nunca se saiba "verdadeiramente", mas vamos ver como ele era e, como ele é visto pela história e pela musicologia. Pois a questão ainda provoca ardentes debates entre os musicólogos e historiadores.
A historiadora Tânia Regina da Racha Unglaud afirma que:

Durante o período do Estado Novo, nosso país vivenciou o momento histórico de maior valorização da música no ambiente educacional. Esta valorização se materializou através do uso do canto orfeônico em caráter obrigatório em toda a rede escolar, mas não afetou somente o ambiente acadêmico, pois se desdobrou e ampliou-se nas grades manifestações cívicas que mobilizaram a população em geral sob as vistas coniventes e até mesmo interessada da elite intelectual da nação (UNGLALD, 2005, p. 149).

Conforme a autora, a música teve durante o Estado Novo esse "surto" de mérito no ambiente escolar, porém, sob vistas coniventes e até mesmo interessadas da elite intelectual da nação. Ou seja, não é o povo nem Villa-Lobos que descobriram num piscar de olhos os benefícios da música para a vida das pessoas e para a identidade do povo. É um projeto musical e um regime ditatorial que vão se encontrar num momento de muito investimento na "imagem idealista" de Vargas, e um maestro entusiasmado, recém-chegado da França, com um discurso afinadíssimo com os ideais do Estado Novo.

Para Alberto Paranhos, o projeto Villa-lobiano no Estado Novo não era tão romântico assim. Representa um:

Personagem ímpar da cena artística brasileira, cuja fama já transbordara as fronteiras nacionais, Heitor Villa-Lobos, compositor e regente, puxava o coro da "unanimidade nacional" em torno do "Estado Novo" e seu "chefe". Autor, entre outras peças de exaltação ao regime, da "Saudação a Getúlio Vargas", composta em 1938, o maestro empunhava a bandeira do canto orfeônico. Defensor, ao lado de outros músicos modernistas, de uma proposta musical 
nacionalista, sob a capa protetora do Estado, ele concebia o canto coral como arma de combate ao individualismo. A seu ver, a música deveria exteriorizar a conciliação das classes sociais, funcionando como uma alavanca para a integração social e política sob a batuta estatal. Daí a importância que atribuía à prática do canto coral: ao entoarem, irmanados, as composições de celebração à disciplina e ao civismo, seus integrantes fariam juras de amor à pátria. Pátria que, segundo Villa-Lobos, necessitava do trabalho disciplinado, em um clima de ordem, para decolar rumo ao desenvolvimento (PARANHOS, 1999, p. 41).

Paranhos analisa Villa-Lobos, vemos no texto acima, como um intelectual do Estado Novo engajado num projeto musical, projeto que muito interessava ao Governo, configurando-se numa política governamental que visava à integração da nação! O projeto previa a criação de corais infantis nas escolas, todas as crianças iriam aprender a cantar, de preferência os hinos oficiais, e canções especialmente compostas para tal projeto escolar; um curso de música para professores e alunos. Os professores aprenderiam a cantar e, aprenderiam também história da música. Ler partitura era uma parte do curso separado da ideia de cantar, pois o maestro estava desenvolvendo um método próprio para as crianças lidar com a parte teórica da música, chamava-se de regras e de normas, de modo que não desestimulasse os alunos. Paranhos percebe no discurso do maestro, de acordo com o nome das canções, "Saudação a Getúlio Vargas", por exemplo, um intelectual afinado com as ideias propagandistas do regime, que faz de tudo para exaltar a figura de Vargas.
Na mesma citação Paranhos ainda capta nos ideais de Villa certa harmonia com os ideais do Estado Novo, a música nacionalista, o combate ao individualismo, a "tão sonhada" conciliação das classes sociais que iria levar a integração social e política desse Novo Estado ou desse Estado Novo. E mais adiante então, o autor descreve o ápice deste megaprojeto de canto orfeônico que pode, por meio da música, "ensinar" essa sociedade, que "precisa" de disciplina, rumar ao progresso. Ou seja, o importante é obedecer sem questionar. $\mathrm{O}$ projeto também previa grandes concertos públicos para demonstrar os resultados dos trabalhos e, estudar a execução e a entonação dos Hinos oficiais. $\mathrm{O}$ mais debatido foi o Hino Nacional. Debatido, porque para o desespero do maestro, o hino nacional era cantado de várias formas diferentes.

Wisnik, seguindo um raciocínio parecido com o de Paranhos, coloca que:

O Estado Novo explicita as relações entre a música e a política no Brasil de um modo muito significativo. Tomando a exaltação do trabalho, juntamente com o ufanismo nacionalista, como base de sua propaganda, o Estado subvenciona a música como instrumento de pedagogia política e de mobilização de massas, tentando faze-la portadora de um ethos cívico e disciplinador. É durante esse episodio que Villa-Lobos leva adiante o programa de implantação do canto orfeônico nas escolas do País, tomando a atividade coral como um veículo de introjeção do sentimento de autoridade (WISNIK, 2000, p. 120).

O autor da citação vê no Estado Novo uma estreita relação entre a pedagogia musical e a política. Wisnik percebe a necessidade e a intencionalidade do regime em mobilizar 
massas, e a capacidade da música em transformar isso em realidade da maneira mais discreta possível - discreto no sentido de que: se todos estão ouvindo e cantando músicas 'belas', não tem nada de errado com isso, afinal música não faz mal a ninguém. E assim o Estado Novo vai convidar e dar suporte para que Villa implante seu projeto musical nas escolas de todo o país. E automaticamente toda essa vibração da música nacionalista de Villa-Lobos se transformará em um "ótimo projeto para o país". Deve-se atentar que o Estado Novo vai levar o "benefício" da música para todas as pessoas, mas em benefício de quem?

Wisnik continua citando que, nessa utópica sociedade disciplinada, "o projeto do canto orfeônico quer fazer com que o corpo social se exprima, desde que não faça valer seus direitos, mas que se submeta ao culto e às ordens de um chefe" (WISNIK, 1983, p. 120).

Agora o autor expõe claramente que a 'sociedade disciplinada' não existe e não existirá - ela é utópica, um sonho inatingível, e que nem o canto orfeônico, que fará essa sociedade se expressar - mas não se expressar de maneira independente -, irá tirá-la de sua submissão social. Até porque o canto orfeônico será implantado nas escolas, com um repertório ufanista e nacionalista. Limitando claramente o chamado 'ideal modernista' de liberdade e originalidade. Todo o aparato de desenvolvimento do projeto musical será muito bem vigiado, pois cada escola era obrigada a mandar seus programas de música e festividades para serem avaliados pelo governo. O projeto acontece, mas ele segue regras. E o maestro Villa concordou com isso?
Essa visão, no entanto, não é a da maioria dos musicólogos estudiosos da vida e da obra do Maestro. Vejamos o que dizem alguns deles: "ao bem-sucedido período parisiense seguiu-se a controvertida atuação do compositor no campo da educação musical no governo de Getúlio Vargas, discutida criticamente por José Miguel Wisnik" (VOLPE, 2006, p. 28). A autora vê nas críticas ao projeto de Villa que há divergências, que há polêmica, o maestro pode sim ter sido um instrumento do Estado Novo, mas também pode sim ter sido um idealista da música brasileira! Ou não?

Vejamos outro:

Um grande compositor é aquele que consegue criar uma linguagem própria para exprimir-se musicalmente. Villa-Lobos foi capaz de assimilar e utilizar em suas composições formas musicais que absorveu ao longo de sua trajetória. De fato, ele próprio o afirmava: no final de sua carreira, como responsável pelo projeto de educação musical do governo Vargas, ele criou um método de ensino de criação de melodias que se baseava na percepção básica dos sons e sua transformação em matéria-prima musical. Sons da natureza como ventanias, canto de pássaros ou pingos de água eram utilizados como exemplos de ruídos que poderiam ser processados e incorporados em uma obra de arte (GUÉRIOS, 2006, p. 36).

Segundo Guérios, Villa foi um grande compositor, e criador de uma linguagem própria para exprimir-se musicalmente. Podemos ainda constatar em muitas biografias que foram feitas sobre a vida e a obra de Villa-Lobos algumas das controvérsias na execução do projeto. Vasco Mariz, um de seus biógrafos mais importantes nos traz uma fala do maestro explicando seu proje- 
to musical para as escolas no Estado Novo. Ficando então decidido o ensino da música e do canto orfeônico nas escolas do Distrito Federal. O primeiro trabalho de Villa-Lobos foi apresentar ao público, em geral, e principalmente aos pais dos alunos, as razões da utilidade de tal ensino, para que todos compreendessem a necessidade da música na educação da criança. Escrevia Villa-Lobos:

Só a implantação do ensino musical na escola renovada, por intermédio do canto coletivo, seria capaz de iniciar a formação de uma consciência musical brasileira. Efetivamente, o canto coletivo é uma síntese de fatores educacionais os mais complexos. Em primeiro lugar, reúne todos os elementos essenciais à verdadeira formação musical. Em segundo lugar, o canto coletivo, com o seu poder de socialização, predispõe o individuo a perder no momento necessário a noção egoísta da individualidade excessiva, integrando-o na comunidade, valorizando no seu espírito a idéia da necessidade de renúncia e da disciplina ante os Imperativos da coletividade social, favorecendo, em suma, essa noção de solidariedade humana, que requer da criatura uma participação anônima na construção das grandes nacionalidades. Um outro aspecto educativo que se torna evidente é o auxílio que o canto coletivo veio prestar à formação moral e cívica da infância brasileira. O hábito de comemorar as grandes datas e de festejar os grandes acontecimentos da história do Brasil encontrou nessa nova disciplina um enorme propulsor de energia cívica e uma consciência musical autenticamente brasileira. E as geraç̃oes novas, tocadas por esse sopro renovador e dinamogênico, colocarão acima de todos os interesses humanos o símbolo sagrado da pátria (MARIZ, 2005, p. 96).

A fala do maestro é riquíssima em possibilidades de analises. A citação foi ti- rada da obra de Vasco Mariz - musicólogo - que coloca certo entusiasmo de músico na fala do maestro. Entusiasmo que teria outro olhar na perspectiva de um historiador - que talvez analisasse essa fala como um discurso muito bem afinado com o regime de Vargas. Villa define em três aspectos a importância do seu projeto.

Primeiro o maestro pedagogicamente coloca a importância de se estudar música para a formação musical do indivíduo. Em seguida ele fala diretamente dos benefícios da música na vida das pessoas, expondo seu grande poder de socialização e sua função de fazer o indivíduo perceber o seu papel no coletivo, deixando de lado o egoísmo para participar na construção de uma sociedade mais humana. Num terceiro momento, o maestro fala da importância do canto orfeônico na formação cívica do indivíduo e na sua formação moral. Mas o maestro insiste na ideia de que isso contribui muito para uma consciência musical autenticamente brasileira.

Villa-Lobos não se faz de desentendido em relação à ativa participação e interesse do Governo de Vargas na elaboração e na execução do seu projeto musical. Falando do canto orfeônico como fator de civismo e de disciplina coletiva social, Villa faz uma reflexão sobre o projeto, e tenta dar uma idéia de limite para o ufanismo frenético dos discursos. Dizia Villa-Lobos:

Entretanto, para corresponder à sua verdadeira finalidade educacional, o canto orfeônico não deve limitar-se a uma simples exibição pública das qualidades mais ou menos musicais da infância. Mas deve participar da vida cotidiana da escola, imprimindo ao ambiente escolar uma impres- 
são de sentimento cívico, de solidariedade e de disciplina. Como Também nunca será demasiado insistir na finalidade pragmática do canto orfeônico. E não confundir o seu objetivo cívico-educacional com outras exibições de ordem puramente estética, que não visam senão ao prazer imediato da arte desinteressada, sem um caráter socializador. Nas exortações cívicas, é necessário que não se exagere na tese de que o Brasil e a sua gente têm tudo de maior e melhor no mundo inteiro. Porque um aluno observador e viajando acabara descrendo desses elogios cívicos, quando refletir e conjeturar: como é que tudo no Brasil é maior, com seus quatro séculos e meio de existência e mais de cem anos de independência, se a maioria do seu povo prefere muitas coisas do estrangeiro como sejam: música, dança, pintura, escultura, modas, certos hábitos etc. (MARIZ, 2005, p. 125).

É impossível falar do canto orfeônico sem mencionar o Sema (Superintendência de Educação Musical e Artística), instituição criada em 1932 por Anísio Teixeira, então secretário da Educação da Prefeitura do Distrito Federal, para que Villa-Lobos executasse o projeto orfeônico que havia iniciado em São Paulo no final de 1930.

Com o objetivo de desenvolver o estudo da música nas escolas primárias e nas de ensino secundário e profissional. De acordo com o decreto $\mathrm{n}^{\mathrm{o}} 18.890$, de abril de 1931, sobre a reforma do ensino, tornou-se obrigatório o ensino de canto orfeônico nas escolas acima citadas (primárias, secundárias e profissionais). Aos interventores e diretores de instituições de todos os estados foi enviado, em 1933, um apelo no sentido de que se interessassem pela propagação de orfeões escolares. Nesse documento, eram expostas as vantagens que poderiam resultar para a formação da unidade nacional, não só pela prática coletiva do canto orfeônico como para a uniformização da nova orientação do ensino. Esse apelo foi atendido pelo governo de vários Estados que, para torná-lo realidade, enviavam professores ao Rio para estágios no Orfeão. Ali eles iam adquirir os conhecimentos básicos à criação de grupos orfeônicos nas suas escolas (MAIA, 2000).

Foi então criado o Curso de Pedagogia de Música e Canto Orfeônico para facilitar aos professores das escolas públicas a prática da teoria musical e a técnica dos processos orfeônicos. Mas para que esse curso pudesse desenvolver-se, foram convidadas as pessoas que tivessem formação musical e o desejo de se integrar no referido curso. Esse convite teve a mais franca acolhida, pois na aula inicial compareceram artistas famosos do meio musical brasileiro e, ainda, assistentes e professores da Escola Nacional de Música. E como parte imprescindível desse Curso de Pedagogia de Música e Canto Orfeônico, foi criado o Orfeão de Professores (MAIA, 2000).

Preocupando-se com os aspectos didáticos, Villa tecia, antes de cada audição, uma série de considerações e comentários sobre a vida e a obra de cada compositor a ser executado ou, ainda, abordava questões sobre morfologia e orquestração. O maestro demonstrava uma preocupação histórico-socio-cultural com o aprendizado da música (MAIA, 2000).

Já Arnaldo Contier aponta que, durante a realização das festas cívicas, foram cantados os hinos P'ra Frente, Ó Brasil! Meu País e Brasil Novo, e muitas outras músicas de caráter ufanista que exaltavam o governo de 
Vargas, como o Canto do Page. Villa-Lobos, em janeiro de 1919 escreve "Meu País":

Do céu nos fala, alto o cruzeiro/ Com voz de estrelas e nos bem diz:/ Levanta a fronte que és brasileiro!/ Lembra qu'és filho deste país! Vê como é lindo!/ Seu povo altivo!/ Verdes campos e o céu d'anil!/ então, num brado ardente e vivo - e exalto a glória do meu Brasil! Côro: Brasil! Brasil! Ó terra dum povo forte e audaz,/ Invicto és tu na luta e triunfador na paz! (VITALE, 1940, p. 48-49).

Essa metódica propaganda dirigida às massas no sentido de atraí-las para as figuras de Villa-Lobos ou de Getúlio Vargas acabou se tornando um novo recurso bastante eficaz na sacralização do conceito de brasilidade nos campos da música e da política. Contier percebe que o sucesso de público e de crítica alcançado por Villa-Lobos em seu espetáculo programado para o Parque Antártica animou-o de tal maneira que, em fins de maio de 1931, ele repetiu esse tipo de evento no campo da Associação Atlética São Bento, um dos mais amplos recintos fechados existentes na cidade de São Paulo. O público presente nessa "exortação" cívica congregava segmentos representativos de todas as camadas sociais (VITALE, 1940). É curioso falar do sucesso de público e de crítica, já que quem mandava na crítica era o governo, e no público (alunos de escolas públicas) também tinha interferência do poder público.

Rodolfo Coelho de Souza, professor de composição da USP de Ribeirão Preto, sai em defesa do maestro num artigo publicado na revista Diapason intitulado: "O Pelé da Música Brasileira”, em que ele dizia:
Essa disputa inútil a respeito da ética no uso do folclore nos faz lembrar, por outro lado, da competência de Villa-Lobos na autopromoção. Ele é, sob todos os aspectos, um homem de seu tempo que teve a sensibilidade empresarial de perceber que na era da indústria cultural o sucesso dependeria da propaganda nos meios de comunicação. Propaganda e mitificação em larga escala se misturaram a fatos reais na criação de uma imagem pública do compositor. Se, em vida, essa estratégia rendeu-lhe dividendos, a longo prazo trouxe prejuízos para a avaliação de sua obra, que dificilmente escapa de certos preconceitos fortemente arraigados no imaginário do público e dos intérpretes. Mas, à medida que o tempo passa, o conluio com a máquina propagandista do Estado Novo nos anos 30 e o desejo de assimilação pela indústria cinematográfica americana nos anos 40, freqüentemente abominados como pecado mortais imperdoáveis, tendem a ser julgados mais como valores de uma época distante e menos como desvios de caráter (SOUZA, 2006, p. 40-42).

Num outro momento Souza diz que:

Pelé costuma dizer que nós detestamos os brasileiros que fazem sucesso. Segundo ele, nosso esporte favorito não é o futebol, mas sim criticar e destroçar nossos ídolos. Concordaria com ele, não fosse a ressalva fundamental de que esse comportamento não é privilégio dos brasileiros, mas do ser humano em geral. Villa-Lobos, o mito, não fugiu à regra. De tempos em tempos ressurgem as críticas de que ele foi um fascista vendido ao Estado Novo de Getúlio, um cabotino e mentiroso. Seria preciso desmistificá-lo, trazer a verdade à luz. E tome-se malhação de Villa-Lobos (Souza, 2006, p. 40-42).

Entretanto, certa vez na arena do canto de uma das escolas, Villa contatou com tristeza que as crianças não sabiam cantar 
os hinos patrióticos, principalmente o Hino Nacional Brasileiro. E quando notou que nem as professoras sabiam também cantar o nosso hino, aí o maestro ficou estarrecido. Mas como é possível? Cada menino ou cada escola cantando com o sotaque de sua região, e com a agravante, o conhecimento imperfeito da música e da letra. Villa então baixou um ato proibindo que o Hino Nacional fosse cantado nas escolas até que uma comissão de professores estabelecesse uma interpretação-modelo (MARIZ, 2005). Villa baixou um "ato", proibindo o hino de ser cantado nas escolas.

Mariz explica polemica em torno da proibição e explicita sua posição. A proibição de o hino ser cantado nas escolas repercutiu como uma bomba, um escândalo! Os jornais exploraram ao máximo a medida do "tresloucado" maestro. Mas Villa estava tranquilo, com a consciência serena. $\mathrm{O}$ governo lhe dera carta branca. Só tinha de prestar contas a seu secretário da Educação. Portanto desassossegado estaria se consentisse em deixar que o hino do nosso Brasil continuasse tão sacrilegamente mal cantando. E a culpa não era dos garotos e nem das professoras. Era um vício que vinha de longe e que precisava ser corrigido. Assim, a medida certa era a suspensão provisória do hino até que as professoras aprendessem com ele, Villa-Lobos, a cantá-lo, para depois então ensiná-lo às crianças. A verdade era essa. Queriam botar lenha na fogueira, fazer de sua acertada medida um caso nacional? Com um balde d'água, ele apagaria essa falsa fogueira esse cacarejo de maus patriotas. Sua medida era lógica, sensata. Os meninos das escolas voltariam a cantar o hino, mas a cantar como o nosso hino merece e deve ser cantado (MARIZ, 2005).

Mas será mesmo que o maestro só queria ver o Brasil cantar? Ou o maestro deixou-se "usar" e, usar sua música pelo Estado para legitimar um regime golpista:

A relação música nacionalista-Estado não pode ser caracterizada conforme uma visão simplista que imagina o Estado interferindo diretamente no campo cultural, em face de interesses político-ideológicos que o levariam até à tentativa de estruturação de um projeto hegemônico nessa área. No caso da música, a prática política de alguns intelectuais envolvidos sentimentalmente pela proposta de nacionalização da música brasileira voltou-se para o Estado como o único agente capaz de interferir no seio da sociedade, sem nenhum interesse partidário ou de classe, tão-somente como unificador cultural da nação solapada pela música estrangeira erudita e popular (CONTIER, 1998, p. 27).

Talvez nunca venhamos a ter um consenso entre historiadores e musicólogos sobre a questão: o Estado Novo usou Villa-Lobos e sua música para legitimar seu projeto de poder? Ou: Villa-Lobos usou a máquina do Estado para por em prática seu idealista projeto de fazer o Brasil cantar!? Que Villa-Lobos compôs muito durante o Estado Novo é inegável, mas que suas músicas serviram para 'educar' e para 'unificar' a nação no Estado Novo também é inegável.

Se for o caso, a música de Villa-Lobos terá, acima de tudo, a riqueza da ambigüidade. Riqueza daqueles que levam seus projetos a um ponto de tal extremismo que acabam por produzir o inverso do que desejavam. Nesse sentido, os momentos mais impressionantes da obra de Villa-Lobos não são os que parecem sintetizar o Brasil, mas aqueles nos quais, à força de tentar levar 
o princípio da unificação ao extremo, ele acaba por perder o Brasil. E, no que diz respeito o nacionalismos musicais, vale o dito de Nietzsche: 'É necessário saber perder-se para poder se encontrar' (SAFATLE, 2006, p. 45).

Por fim, "Para conhecer Villa-Lobos é preciso ouvir sua música" (RIBEIRO, 1987, p. 21). Nesse escrito, não é possível ouvir a música de Villa-Lobos, como também não é possível reviver o Estado Novo. Mas isso não torna o trabalho mais atraente ou menos curioso. Como toda pesquisa científica, o leque de possibilidades vai aumentando à medida que se vai trilhando o caminho das possíveis respostas e futuras indagações. Heitor Villa-Lobos está morto, sua música e sua vida são ouvidas e discutidas em todo mundo; sua música é estudada e gravada em vários países do mundo. O músico que queria ver o Brasil cantar, hoje é interpretado por muitos. E o Estado Novo? Esse também acabou, em todo mundo procura-se acabar com as ditaduras, com as censuras, com as torturas, com as perseguições. Agora se o regime usou o maestro e sua música para dominar e influenciar a massa, é verdade. Muitos historiadores perceberam essa ligação entre o Músico e a era Vargas. Hoje, a música é obrigatória no ensino fundamental. É esse o triunfo de Villa-Lobos? É claro que não! $\mathrm{O}$ momento é outro. $\mathrm{O}$ contexto é outro. O governo é outro [...] Assim, as pesquisas continuam, contribuindo para a compreensão de cada época, com seus mecanismos de governo e engrenagens sociais. Finalizamos o escrito citando Marcos Napolitano "Afinal, todo pesquisador, jovem ou experiente, é um pouco fã do seu objeto de pesquisa. Em se tratando de música, essa re- lação deliciosamente perigosa se multiplica por mil" (NAPOLITANO, 2002, p. 54). Isso talvez tenha acontecido com os autores.

\section{Abstract}

Getúlio Vargas, during the time he was in power, especially during the Estado Novo sought to co-opt many intellectuals - painters, writers and musicians in order to legitimize itself in power. But to what extent these intellectuals joined or not, or does not have support for the Vargas government? This issue has caused much debate and analysis in the gym. The master Heitor Villa-Lobos experienced the period when Vargas was in power and worked for his government. Thus, this paper seeks to demonstrate how the maestro Villa has been viewed by historians and how he was seen by musicologists during the Estado Novo. Thus arises a fiery debate among musicologists and historians on the posture of the conductor, as an intellectual and as a coordinator of a music education program, during the Estado Novo.

Keywords: Dissonant voices. Villa Lobos. New State.

\section{Resumen}

Getúlio Vargas, durante el tiempo que estuvo en el poder, sobre todo durante el Estado Novo intentó cooptar a muchos intelectuales - pintores, escritores y músicos, para legitimarse en el poder. Pero ¿hasta qué punto estos intelectuales unido o no, o no tiene el apoyo al gobierno de Vargas? Este tema ha causado 
mucho debate y análisis en el gimnasio. El maestro Heitor Villa-Lobos experimentó el período en que Vargas estaba en el poder y trabajó para su gobierno. Por lo tanto, este trabajo trata de demostrar cómo el maestro Villa ha sido visto por los historiadores y cómo había sido visto por los musicólogos durante el Estado Novo. Así surge un ardiente debate entre los musicólogos e historiadores sobre la postura del conductor, como intelectual y como coordinador de un programa de educación musical, durante el Estado Novo.

Palabras clave: Voces disonantes. Villa Lobos. Nuevo Estado.

\section{Notas}

1 Não cabe, neste trabalho, fazer uma discussão aprofundada sobre o que é samba. Podemos encontrar sobre o assunto em: VIANA, Hermano. O mistério do Samba. 5. ed. Rio de Janeiro: Jorge Zahar Ed.; Ed. UFRJ, 2004.

2 Trecho de uma conferência que Mário de Andrade fez no Rio de Janeiro em 1942, se encontra na obra: A Vida dos Grandes Brasileiros, ISTOÉ, 2001.

3 O termo classe é aqui empregado como: conjunto de pessoas que têm a mesma função, os mesmos interesses.

\section{Referências}

A VIDA DOS GRANDES BRASILEIROS, VILLA-LOBOS. Editores: Domingo Alzugaray/Cátia Alzugaray. São Paulo: Ed. TRES LTDA, 2001.

CANTO ORFEÔNICO. São Paulo, Irmãs Vitale, v. 1, 1940, p. 48-49.

CONTIER, Arnaldo D. Passarinhada do Brasil: canto orfeônico, educação e getulismo. Bauru: EDUSC, 1998.
DENNING, Michel. A cultura na era dos três mundos. Trad. de Cid Knipel. São Paulo: Francis, 2005.

GIACOMO, Arnaldo de Magalhães. Villa-Lobos/Alma sonora do Brasil (Biografia para a Infância e a Juventude). Melhoramentos. Prêmio Jabuti. São Paulo, 1960. p. 79-81.

GOMES, Roberto. Crítica da razão Tupiniquim. São Paulo: FTD, 1990.

GUÉRIOS, Renato Paulo. A dimensão humana da criação artística. Diapason, n. 3, jul./ago. 2006.

LENHARO, Alcir. Sacralização da Política. Capinas 2. ed. SP: Papiros, 1986.

MAIA, Maria. Villa-Lobos: alma brasileira. Rio de Janeiro: Contraponto - PETROBRAS, 2000.

MARIZ, Vasco. Heitor Villa-Lobos. Belo Horizonte: Itatiaia, 1989. (coleção reconquista do Brasil. 2. série; v. 167).

. Villa-Lobos - O homem e a obra. Academia brasileira de Música. Rio de Janeiro, 2005.

MENDES, Gilbert. O verdadeiro Tropicalista. Diapason, n. 3, jul./ago. 2006.

MORAIS, Marieta de; CONDE SÁ, Surama. O Brasil republicano: a crise dos anos 1920 e a revolução de 1930.

NAPOLITANO, Marcos. História e música: história cultural da música popular. Belo Horizonte: Autêntica, 2002.

PELLEGRINI, Tânia; FERREIRA, Marina. Palavra e arte - $2^{a}$ grau. São Paulo: Atual.

PARANHOS, Adalberto. O roubo da fala: origens da ideologia do trabalhismo no Brasil. São Paulo: Editorial, 1999.

RIBEIRO, João Paulo. O pensamento vivo: Villa-Lobos. São Paulo: Martin Claret, 1987.

SAFATLE, Vladimir. A riqueza da ambigüidade. Diapason, n. 3, jul./ago. 2006.

SOUZA, Coelho Renato. O Pelé da música Brasileira. Diapason, n. 3, jul./ago. 2006. 
UNGLALD, Tânia Regina da Rocha. Música e nacionalismo em um projeto de hegemonia política. Esboços n. 14. Revista do programa de pós-graduação em história da UFSC, Florianópolis, v. 12, n. 4, p. 149-162, jul./dez. 2005.

VELLOSO, Mônica Pimenta. O Brasil republicano. Os intelectuais e a política cultural do Estado Novo.

VOLPE, Alice Maria. O Mito: A música brasileira começa comigo. Diapason, n. 3, jul./ago. 2006.

WISNIK, JOSÉ MIGUEL. Algumas questões de música e política. São Paulo: Ática, 2000.

Getúlio da Paixão Cearense (Villa-Lobos

e o Estado Novo). Brasiliense. 2. ed. São Paulo, 1983. 